\title{
OPTIMALISASI PENGGUNAAN LEGO DALAM PEMBELAJARAN MATEMATIKA SMP UNTUK MENDUKUNG IMPLEMENTASI KURIKULUM 2013
}

\author{
Sri Rejeki, Nining Setyaningsih, Muhamad Toyib \\ Prodi Pendidikan Matematika \\ Fakultas Keguruan dan Ilmu Pendidikan \\ Universitas Muhammadiyah Surakarta \\ J1. A. Yani Tromol Pos I Pabelan, Kartasura, Surakarta, Indonesia \\ Email :sr131@ums.ac.id
}

\begin{abstract}
This community service aims at transferring knowledge and skill aboutusing LEGO in mathematics teaching and learning to mathematics teachers. This conducted into three stages of training and two stages of real teaching. The stages of the training were introducing the use of LEGO in mathematics teaching and learning, designingsets of teaching and learningactivities using LEGO as the media, and peer teaching. The real teaching conducted in two stages of three meetings for each stages. Twelve mathematics teachers from five schools of Muhammadiyah in Surakartawere participated in this training. The teachers have technically trained with new experiences using LEGO as media in mathematics learning and have developed five sets of lesson plans for the topics of fractions, sets, proportion, linear equation with one variable, and statistics. The real teaching for the topic offractions was conducted in two of those five schools. The results indicate the learning activities designed support students understanding and attitude in mathematics.
\end{abstract}

Keywords: LEGO, Matematika, Kurikulum 2013

\section{PENDAHULUAN}

Pendidikan Indonesia, khususnya pada bidang matematika dapat dikatakan tertinggal dari negara-negara di dunia, bahkan dari negara-negara di Asia Tenggara. Hal ini ditunjukkan oleh hasil studi Trends in International Mathematics and Science Education (TIMSS) yang menempatkan Indonesia pada rangking 38 dari 42 negara, dengan rata-rata skor matematika siswa di bawah rata-rata skor internasional (Provasnik, Stephen; Kastberg, David ; Ferraro, David; Lemanski, Nita ; Roey, Stephen; Jenkins, 2013). Sementara itu, berdasarkan studi tiga tahunan Program for International Students Assessment (PISA), pada tahun 2012 Indonesia menempati posisi 64 dari 65 negara, jauh di bawah
Singapura (rangking 2), Vietnam (rangking 17), Thailand (rangking 50), dan Malaysia (rangking 52)(OECD, 2014).

Ketertinggalan ini tentunya disebabkan oleh banyak faktor, salah satunya berkaitan dengan praktik pembelajaran matematika di sekolah. Beberapa penelitian menyimpulkan bahwa prestasi belajar matematika dipengaruhi oleh kompetensi guru, yaitu tentang bagaimana guru mengajarkan matematika (Hill, Rowan, \& Ball, 2013), perangkat pembelajaran (White, 2012), dan pelaksanaan pembelajaran matematika di kelas (Hiebert \& Grouws, 2004).

Pada dasarnya, ketiga hal tersebut sangat berkaitan karena kompetensi guru dalam mengajarkan matematika meliputi bagaimana merancang desain pembelajaran 
dan mengimplementasikan perangkat pembelajaran yang pada akhirnya dapat meningkatkan prestasi siswa dalam matematika.

Berdasarkan observasi dan wawancara yang dilakukan dengan beberapa Sekolah Menengah Pertama(SMP) di daerah Surakarta dan sekitarnya, praktek pembelajaran matematika masih menggunakan pola teacher centered. Selain itu guru belum memaksimalkan pembelajaran matematika dengan memberikan permasalahan realistik maupun, menggunakan alat peraga ataupermainan. Hal ini disebabkan oleh keterbatasan kemampuan guru dalam mengkonsep dan merancang pembelajaran yang melibatkan permasalahan realistik maupun alat peraga dan pemainan.

Oleh karena itu dilaksanakan pengabdian kepada masyarakat dalam bentuk pelatihan penggunaan permainan $L E G O$ dalam pembelajaran matematika SMP. Kegiatan pengabdian kepada masyarakat ini bertujuan untuk untuk mentransfer IPTEKS inovasi pembelajaran matematika SMP kepada guru SMP Muhammadiyah dengan memberikan pengetahuan dan keterampilan guru bentuk pelatihan interaktif penggunaan permainan $L E G O$ dalam pembelajaran matematika. Pelaksanaan pelatihan penggunaan permainan $L E G O$ pada guru SMP mitra dirancang dalam beberapa tahap, antara lain: perencanaan, pelaksanaan, follow-up (produk hasil pelatihan), dan evaluasi.

Mengajar matematika yang efektif memerlukan pemahaman tentang apa yang siswa ketahui sebelumnya dan perlukan untuk belajar dan kemudian memberikan tantangan dan mendukung mereka untuk mempelajarinya dengan baik (NCTM), 2000). Salah satu inovasi yang mengakomodasi pengetahuan awal, memberikan tantangan, dan mendukung kreativitas siswa adalah mengintegrasikan permainan edukatif dalam pembelajaran. Hal ini sesuai dengan pendapat Nath (Nath \& Szucs, 2014)yang menyebutkan bahwa siswa belajar melalui permainan.

Permainan edukatif adalah aktivitas bermakna yang di dalamnya terdapat urutan kegiatan tertentu sesuai aturan yang dibuat guru untuk mencapai tujuan pembelajaran (Najdi \& El Sheikh, 2012). Najdi dan El Sheikh (Najdi \& El Sheikh, 2012) menyebutkan beberapa keuntungan penerapan permainan edukatif dalam pembelajaran yaitu: 1) Alat yang baik untuk mempromosikan kemampuan siswa dan membantu siswa memperoleh keuntungan maksimal dari proses pembelajaran, 2) Dapat mengembangkan sikap positif terhadap pembelajaran. Selain itu, Freudenthal (Freudenthal, 1991)menyatakan bahwa matematika adalah aktivitas manusia dan harus dikaitkan dengan realitas. Matematika bukanlah produk jadi yang kita berikan pada siswa melainkan sutu proses yang dikonstruksi oleh siswa. Ketika pengalaman belajar melibatkan aktivitas fisik secara langsung dan menyenangkan salah satunya melaui permainan, siswa akan merasa nyaman dan termotivasi untuk menyelesaikan permasalahan.

Secara tidak sadar bentuk-bentuk $L E G O$ ternyata dapat digunakan dalam kegiatan pembelajaran, hal tersebut sudah dilakukan di beberapa sekolah di Eropa. LEGO dapat memunculkan / mempercepat kreativitas siswa dan membangun kerjasama, serta memfasilitasi guru untuk lebih berkonsentrasi pada proses pembelajaran. Permainan LEGO berkaitan kuat dengan kecakapan matematika dan sangat efektif digunakan untuk mengenalkan dan memperkuat kemampuan matematika (Nath \& Szucs, 2014).

Penggunaan Permainan LEGO dalam pembelajaran merupakan langkah inovasi dalam pembelajaran matematika, sehingga siswa mampu menguasai kemampuan yang esensial, diantaranya adalah: 1) Kemampuan pemecahan masalah: pemahaman latihan pemecahan masalah matematika, penalaran, ketekunan, ketepatan, dan pemodelan,; 2) Kemampuan yang komprehensif: melakukan pembelajaran matematika melalui aktifitas yang meliputi bilangan, operasi, aljabar, pengukuran, geometri, statistika dan peluang; 3) Kemampuan kolaborasi: kemampuan 
siswa untuk bekerja sama dalam tim maupun individu; 4) Kemampuan Komunikasi : mengemukakan pendapat, mendengarkan pendapat dan menyajikan penyelesaian. Kemampuan tersebut diharapkan mampu diperoleh melalui kegiatan pembelajaran yang memberikan kebebasan kepada siswa untuk mengembangkan potensi dalam memahami materi. Kegiatan pembelajaran seperti itu sejalan dengan kurikulum 2013. Kurikulum 2013 memberikan kesempatan kepada siswa untuk mengkontruksi konsep dengan tahapan pembelajaran "mengamati, menanya, mengumpulkan informasi/ eksperimen, mengasosiasikan/mengolah informasi dan mengkomunikasikan" (Kemdikbud, 2013).

\section{METODE KEGIATAN}

Metode pendekatan yang ditawarkan untuk memecahkan permasalahan guruguru SMP mitra dalam pengabdian ini adalah participant active learning (peserta pelatihan berpartisipasi secara aktif dalam kegiatan pelatihan dan pendampingan pelatihan dan pendampingan penggunaan $L E G O$ dalam pembelajaran Matematika). Dalam penerapannya peserta pelatihan dilibatkan secara aktif, atraktif dan interaktif dalam proses pelatihan penyusunan perangkat pembelajaran Peserta pelatihan juga diberikan kesempatan seluas-luasnya untuk menyumbangkan ide, pendapat dan gagasannya terkait materi pelatihan dan pendampingan.

Berdasarkan pendekatan tersebut, maka metode yang digunakan dalam proses pelatihan dan pendampingan ini adalah:

1. Ceramah

Metode ceramah digunakan untuk menyampaikan materi pelatihan, seperti: pengenalan permainan $L E G O$.

2. Tanya jawab

Metode tanya jawab merupakan suatu cara penyampaian materi untuk pelatihan yang dilakukan dengan tujuan memberikan kejelasan suatu informasi/ pengetahuan dan konsep dengan cara mengajukan pertanyaan dan dijawab oleh pihak lain.

3. Diskusi
Metode diskusi adalah kegiatan yang dilakukan dengan melibatkan peserta pelatihan dan pendampingan dalam membahas dan memecahkan permasalahan yang ditugaskan dalam kegiatan pelatihan dan pendampingan sehingga ada kegiatan saling bertukar pikiran terkait ide dan gagasan masing-masing untuk kemudian melahirkan kesepakatan bersama.

4. Curah pendapat

Metode curah pendapat digunakan untuk mengetahui pendapat peserta pelatihan dan pendampingan terhadap suatu permasalahan. 5. Simulasi

Simulasi merupakan kegiatan yang dilakukan pada tempat terbatas sebagai suatu follow up dari teori yang telah dipaparkan.

Langkah pelaksanaan/prosedur kerja dalam kegiatan pelatihan dan pendampingan optimalisasi penggunaan $L E G O$ dalam pembelajaran Matematika, secara garis besar terdiri atas: 1) tahap perencanaan kegiatan, 2) tahap pelaksanaan kegiatan pelatihan, 3) tahap follow up kegiatan pelatihan dalam bentuk pendampingan praktik ujicoba pembuatan produk hasil pelatihan yang berupa perangkat pembelajaran berbasis permainan $L E G O$ ), dan 4) tahap evaluasi kegiatan.

Pada tahap perencanaan tim pengabdian membuat rencana dan rancangan dengan melakukan kegiatan yang meliputi: 1) studi lapangan dan analisis kebutuhan berdasarkan fakta lapangan guna menentukan rancangan desain pembelajaran dan bahan ajar dengan menerapkan permainan $L E G O$ dalam pembelajaran yang sesuai, 2) pengumpulan sumber rujukan dan studi literatur permainan $L E G O$, dan 3) perencanaan ipteks (materi pelatihan dan pendampingan) yang akan ditransfer kepada guru SMP mitra.

Pada tahap pelaksanaan tim pengabdian memberikan pelatihan dan pendampingan dalam bentuk kegiatan Sosialisasi dan pemberian contoh-contoh permasalahan terkait penggunaan $L E G O$ dalam pembelajaran matematika. Selanjutnya, tim pengabdian melakukanpendampingan dalam 
penyusunan perangkat pembelajaran dengan permainan $L E G O$ sesuai materi matematika di SMP. Perangkat pembelajaran yang telah disusun kemudian dipresentasikan dan diberikan umpan balik serta saran untuk perbaikan.

Tahap follow up kegiatan pelatihan dilakukan dalam bentuk pendampingan praktik ujicoba pembuatan produk hasil pelatihan. Adapun produk hasil pelatihan adalah: Materi pembelajaran matematika SMP berbasis permainan LEGO. Inovasi pembelajaran matematika SMP yang terwujud dalam simulasi dan praktik mengajar matematika SMP menggunakan permainan $L E G O$.

Pada tahap simulasi, peserta pengabdian melakukan simulasi mengajar matematika SMP menggunakan permainan LEGO di depan teman sejawat dan tim pengabdian. Tim pengabdian bertugas mendampingi dan mengevaluasi kegiatan simulasi yang dilakukan oleh peserta. Simulasi yang dilakukan dalam kegiatan pelatihan ini terbatas pada penggunaan Lembar Kerja Siswa (LKS) yang telah disusun oleh guruguru peserta pelatihan.

Evaluasi pada kegiatan pengabdian ini akan dilaksanakan pada dua tahapan evaluasi, yaitu: Evaluasi oleh teman sejawat peserta pelatihan evaluasi hasil pelatihan dan pendampingan oleh tim pengabdian

\section{HASIL DAN PEMBAHASAN}

Pengabdian kepada masyarakat ini dilaksanakan dalam bentuk pelatihan selama satu pertemuan yang dibagi menjadidua tahapan. Tahapan yang pertama merupakan pemaparan dari tim pengabdian tentang pengenalan penggunaan $L E G O$ dalam pembelajaran matematika. Sementara tahap kedua merupakan brain strorming, diskusi dan simulasitentang materi dan pembelajaran matematika SMP menggunakan permainan LEGO.

Padatahapanpertama, selainmemberikan pemaparan tentang penggunaan LEGO dalam pembelajaran matematika berdasarkan literatur yang telah ada, tim pengabdian juga memberikan contoh gagasan materi dan LKS yang memungkinkan penerapan penggunaan permainan $L E G O$ di dalam pembelajaran pecahan. Contoh tersebut menjadi dasar pengembangan perangkat pembelajaran pada materi matematika yang lain. Pengembangan perangkat pembelajaran ini dilakukan pada tahap kedua.

Pada tahapan kedua, secara berkelompok guru mendiskusikan materimateri matematika yang memungkinkan untuk penggunaan permainan LEGO dalam pembelajarannya. Dari hasil diskusi diperoleh empat materi pengembangan yaitu himpunan, perbandingan, persamaan linier satu variabel, dan statistika. Pada pelatihan ini, pengembangan perangkat yang dilakukan oleh guru hanya sampai batas menyusun draf materi dan LKS. Selanjutnya, masingmasing kelompok mempresentasikan desain yang telah dibuat dan melakukan simulasi pembelajaran berdasarkan LKS yang telah disusun. Contoh beberapa permasalahan pada LKS yang telah disusun oleh guru terdapat pada Lampiran.Sebagai follow up dari kegiatan pelatihan ini, dilakukan pendampingan penyusunan perangkat pembelajaran, simulasi pembelajaran melalui peer teaching, dan implementasi pembelajaran dalam real teaching.

Kegiatan pengabdian ini memberikan pengetahuan dan keterampilan bagi guru matematika SMP dalam mengembangkan pembelajaran matematika dengan permainan $L E G O$. LKS yang telah disusun oleh guru-guru peserta pelatihan merupakan produk awal hasil pelatihan. Sebagaimana dikemukakan dalam hasil penelitian (E, 1989) bahwa pelatihan dapat memberi pengaruh positif pada keterampilan dan cara mengajar guru. Akan tetapi, untuk dapat memberikan pengaruh positif terhadap prestasi belajar siswa seperti yang dinyatakan dalam (Hill et al., 2013; White, 2012)diperlukan pendampingan lebih lanjut tentang pengembangan perangkar dan impementasi dalam praktik pembelajaran di sekolah.

Oleh karena itu, keberlanjutan dari 
pengabdian ini berupa pendampingan penyusunan perangkat pembelajaran, simulasi pembelajaran dalam bentuk peer teaching, dan praktik pembelajaran di kelas riil atau rel teaching.

\section{SIMPULAN DAN SARAN}

Penggunaan permainan $L E G O$ dalam pembelajaran merupakan salah satu inovasi dalam pembelajaran matematika yang dapat dikembangkan oleh guru matematika. Untuk memberikan keterampilan ini, dapat diadakan pelatihan dan pendampingan penyusunan perangkat pembelajaran dan praktik pembelajaran. Pada penyusunan perangkat pembelajaran, guru dapat mengeksplorasi penggunaan LEGO dalam pembelajaran matematika, di antaranya pada materi himpunan, perbandingan, persamaan linier satu variabel, dan statistika. Perangkat pembelajaran pada materi-materi tersebut dapat disusun dan diimplementasikan dengan pendampingandaritimahli. Dengandemikian, diharapkan keterampilan yang dimiliki oleh guru dan perangkat pembelajaran yang telah disusun dapat memberikan dampak positif pada prestasi belajar matematika siswa.

\section{PERSANTUNAN}

Artikel ilmiah ini merupakan bagian dari pengabdian masyarakat "IbM Pelatihan dan Pendampingan Optimalisasi Penggunaan LEGO dalam Pembelajaran Matematika SMP untuk Mendukung Implementasi Kurikulum 2013" yang dibiayai oleh Kementrian Riset, Teknologi, dan Pendidikan Tinggi (RISTEK DIKTI). Oleh karena itu Kami mengucapkan terima kasih atas dukungan yang diberikan. Selanjutnya, Kami mengucapkan terima kasih kepada kepala sekolah, guru matematika, dan siswa SMP Muhammadiyah Program Khusus Kottabarat, SMP Muhammadiyah 1 Surakarta, SMP Muhammadiyah 5 Surkarta, SMP Muhammadiyah 1 Kartasura, dan SMP Muhammadiyah Al-Kautsar Program Khusus Kartasura sebagai mitra dari kegiatan IbM ini.

\section{REFERENSI}

(NCTM), N. C. of T. of M. (2000). Principles and Standards for School Mathematics. Reston, VA: National Council of Teachers of Mathematics.

E, P. C. V. A. N. D. E. R. S. (1989). The Effect of a Brief Teacher Training on Studen T Achievement. Teaching \& Teacher, 5(1036), 303-314.

Freudenthal. (1991). Revisiting Mathematics Education. Dordrecht: Kluwer Academic Publisher.

Hiebert, J., \& Grouws, D. a. (2004). The effects of classroom mathematics teaching on students' learning. Second Handbook of Research on Mathematics Teaching and Learning.

Hill, H. C., Rowan, B., \& Ball, D. L. (2013). Effects of Teachers' Mathematical Knowledge for Teaching on Student Achievement. American Educational Research Journal, 1 (September 2013), 1-36. http://doi.org/10.1017/CBO9781107415324.004

Kemdikbud. (2013). Materi Pelatihan Guru Implementasi Kurikulum 2013 SMP/MTs Matematika. Jakarta.

Najdi, S., \& El Sheikh, R. (2012). Educational games: do they make a difference. Social and Behavioral Science, 47, 48-51.

Nath, S., \& Szucs, D. (2014). Constuction play cognitive skills associated with the development of mathematical abilities in 7-year-old children. Learning and Instruction, 32, 73-80.

OECD. (2014). PISA 2012 Results in Focus. Programme for International Student Assessment, 
1-44. http://doi.org/10.1787/9789264208070-en

Provasnik, Stephen; Kastberg, David ; Ferraro, David ; Lemanski, Nita ; Roey, Stephen ; Jenkins, F. (2013). Highlights From TIMSS 2011. National Center for Education Statistics. Retrieved from https://libproxy.library.unt.edu:9443/login?url=http://search.ebscohost. com/login.aspx?direct $=$ true $\& \mathrm{db}=$ eric $\& A N=E D 537756 \&$ scope $=$ site

White, K. M. (2012). The Effect of An Instructional Model Utilizing Hands-On Learning and Manipulatives on Math Achievement of Middle School Students in Georgia. Liberty Univesity. 